\title{
顎裂部骨移植を併用した口唇外鼻修正術
}

\author{
飯野光喜·高田典彦・濱田良樹・金井郁代*
}

石井宏昭 ${ }^{* *} \cdot$ 松浦正朗・瀨戸晥一

\section{Secondary repair of cleft lip and nose deformity by bone grafting to the alveolar cleft}

\author{
Mitsuyoshi Ino $\cdot$ Norihiko TaKada $\cdot$ Yoshiki Hamada $\cdot$ Ikuyo KanaI \\ Hiroaki Ishi ${ }^{* *} \cdot$ Masaro MatsuURA $\cdot$ Kan-ichi Seto
}

\begin{abstract}
A technique for the correction of secondary cleft lip and nose deformity, which employs a bone graft to the alveolar cleft and a cartilage graft to the alar region, is described in this paper. The technique is summarized below.

First, iliac cancellous bone is grafted to the alveolar cleft to provide a bony base for support of the nostril floor and the alar base of the nose. Second, the hypoplastic and displaced alar cartilage is elevated and suspended using the open rhinoplasty method. Third, the cartilage harvested from the nasal septum or ear is trimmed and grafted to the hypoplastic alar cartilage, the lower lateral cartilage, or both.

The use of bone and cartilage grafts compensates not only for scar contraction but also for congenitally missing and hypoplastic bone and cartilage that support the lip and nose. We believe that this technique provides the best chance of producing an excellent long-term cosmetic outcome.
\end{abstract}

Key words: cleft lip and nose deformity (唇裂鼻変形), alveolar bone graft (顎裂部骨移植), cartilage graft (軟骨移植)

緒言

一次手術終了後の口唇裂, 口蓋裂患者の口唇外鼻変 形の原因としては, 軟組織のズレや症痕拘縮の他に， 顎裂という骨欠損による鼻孔底部や鼻翼基部の陥凹， 患側鼻翼軟骨の形成不全および位置異常による鼻尖， 鼻背および鼻翼の変形など, 骨および軟骨の欠損や形 態異常に起因するものも多い1)。よって，口唇外鼻変 形の修正にあたっては，骨および軟骨の修復を合わせ て行った方が良好な口唇外鼻形態がえられやすく，長
期的にも安定すると考えられる.本論文では，われわ れの行っている，顎裂部腸骨移植と鼻翼部軟骨移植を 併用した口唇外鼻修正術の術式について報告し，合わ せて口唇外鼻修正における顎裂部骨移植術の意義につ いて考察する.

\section{手 術術式}

手術は,はじめに顎裂部腸骨海綿骨細片移植を行う。 この際鼻腔底は, 骨が鼻孔底ならびに鼻翼基部裏面に
鶴見大学歯学部口腔外科学第一講座

(主任：瀬戸晥一教授)

・東芝林間病院口腔外科

（主任：金井郁代医長）

・佐久総合病院苗科口腔外科

（主任：石井宏昭医長）

First Department of Oral and Maxillofacial
Surgery, School of Dental Medicine, Tsurumi

University (Chief: Prof. Kan-ichi Seto)

- Department of Oral Surgery, Toshiba Rinkan

Hospital (Chief: Ikuyo Kanai)

- Department of Oral Surgery, Saku Central Hospital (Chief: Hiroaki Ishii)

受付日: 平成 8 年 1 月 29 日 

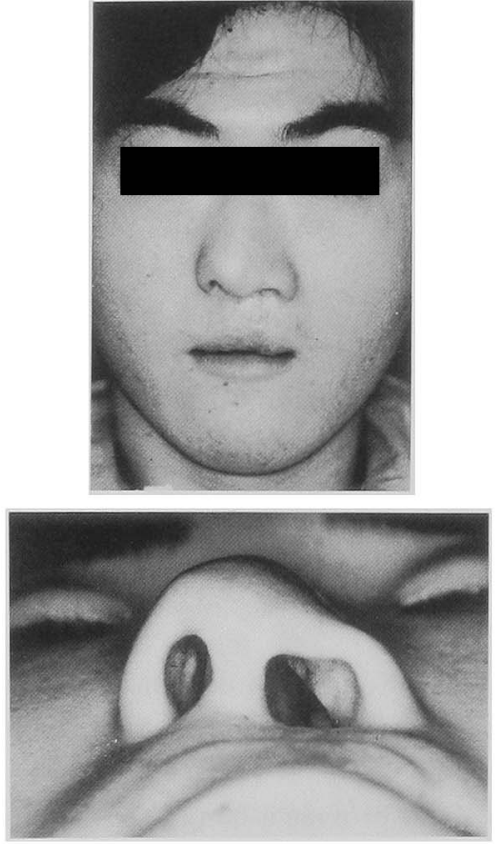

写真 1 提示症例の術前口唇外酋形態
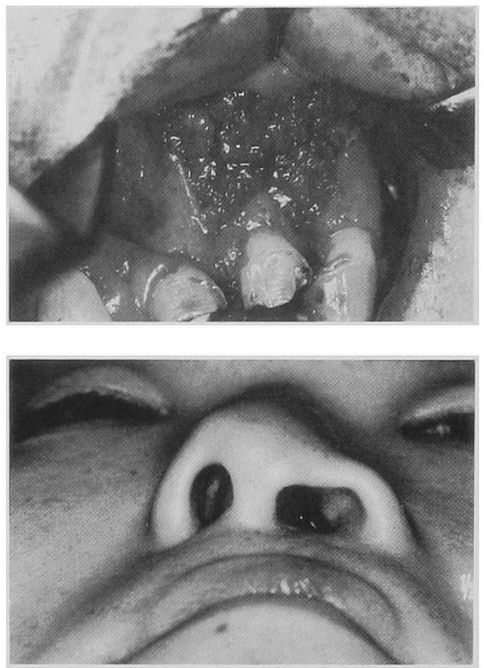
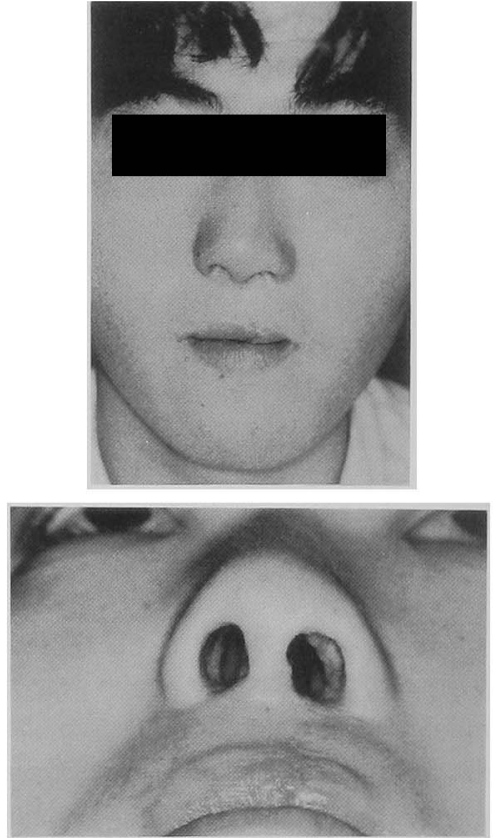

写真 3 提示症例の術後 8 か月の口唇外㑭形態
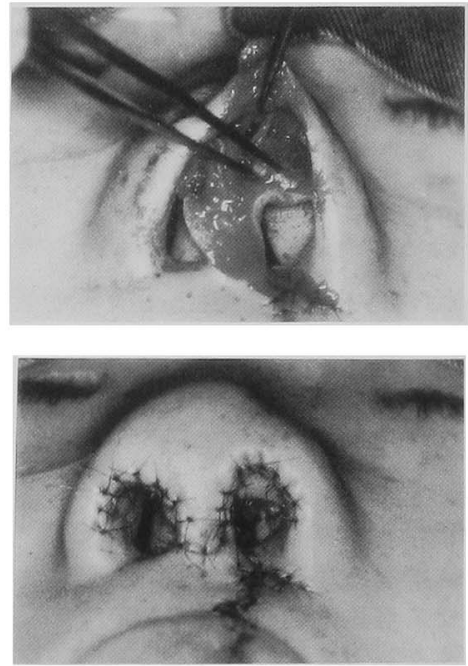

写真 2

左上, 顎裂部腸骨移植術。右上, 口唇鼻修正術 1 : 外側鼻軟骨, 悬翼軟骨上に鼻中隔㳄骨を移植.

左下，䫟裂部腸骨移植術後 3 か月. 鼻孔底, 鼻翼基部の挙上は良好である。右下, 口唇鼻修正術 2 : 手術終了時.

十分充填できるよう，可及的上方で形成する，腸骨海 綿骨細片は, 移植後の吸収を考虑し, 患側の鼻孔底と 鼻翼基部が健側よりも若干高くなるまで充填する。な お鼻翼基部の挙上にあたっては，移植骨を患側梨状孔 側縁から上顎洞側壁にかけて onlay graft すればより 効果的である.口唇修正に続き，Rethi 法に準じた外
鼻修正を行う．悬翼軟骨の挙上のみでは，鼻翼・鼻背 部の扁平化や鼻翼满部の陥凹が残存する症例に対して は，健側と対称となるよう該当部へ耳介軟骨や鼻中隔 軟骨を移植する，最後に，患側の鼻孔外側部に生ずる 鼻前庭ヒダに対して Z 形成等を行い手術を終了する. 


\section{症 例 提 示}

症 例: 21 歳男性. 左側口唇口蓋裂. 外鼻形態では, 斜鼻に加え，患側の鼻孔の拡大，鼻翼の扁平化と下垂， そして鼻孔底と鼻翼基部の陥凹が認められた（写真 1 ). 鼻中隔は健側へ大きく桷曲していた，口腔内所見 では前庭部に大きな鼻口腔瘦が存在した。

処置および経過：はじめに顎裂部腸骨移植術を施行 した。鼻腔底形成に際しては肥大し顎裂に陥入してい た下鼻甲介の下部を切除した ${ }^{2)}$ 術後, 患側の鼻孔底 と鼻翼基部は健側とほとんど同じ高さとなった（写真 2 左上, 左下). 顎裂部骨移植術後 4 か月で, 耳鼻科医 による鼻中隔彎曲修正術とともに, 口唇外鼻修正を行っ た，外鼻修正では，鼻背部と鼻翼部に鼻中隔軟骨を移 植した(写真 2 右上, 右下). 口唇外鼻修正より 8 か月 後の所見では, ほほ左右対称で良好な外鼻形態が得ら れている(写真 3 ).

\section{考察}

口唇裂, 口蓋裂患者の口唇外鼻変形修正の術式につ いては数多くの報告があり，それらの多くは，変形や 組織の亡失の程度に忍じた切開線のデザインや縫合に ついて述べている，また，鼻孔，鼻翼を中心とした可 動性外鼻の修正に際し，鼻背や鼻翼あるいは鼻柱部に， 軟骨，骨または人工物を移植してよりよい外鼻形態を 得ようとする報告も多いところが，顎裂への骨移植 により積極的に鼻孔底や鼻翼基部の陥凹の改善を行う という報告はJackson ら ${ }^{3)}$ の論文以外ほとんど見ら れない。

本邦では, 形成外科領域において丹下 $\left.{ }^{4}\right)$ が口唇裂二 次修正のデザインについて詳細に述べているが，顎裂 は放置するため, 片側性変形では基底となる骨格が不 均斉となり，術後に用いる鼻プロテーゼの彫刻に工夫 を要すると述べている， 口腔外科領域では三村 $\left.{ }^{5}\right)$ が鼻 翼部への耳介軟骨移植を応用した術式について報告し ているが, 鼻翼基部の位置異常ならびに鼻孔底の陥凹 は唇裂手術の際に改善すべきとし，この変形を顎裂へ の骨移植により改善するとの記載は見られない。また， 高戸 1) らは顎裂修復の重要性を指摘し顎裂への骨移 植を行うと述べてはいるが, 彼らの報告も鼻柱または 鼻背部への骨, 軟骨移植が主体であり，顎裂部骨移植 に関してはそれほど具体的に述べているわけではない．

顎裂部骨移植により鼻翼基部と鼻孔底部の陥凹を改 善すると, 多くの場合, 今回示した症例のように患側 外鼻の形態が変化してくる.この外鼻形態の変化は外 鼻修正に少なから影響を与えるものと考えられる。 よって，口唇外鼻修正における顎裂部骨移植は，口唇 裂、口蓋裂患者の顎顔面形態をより正常な解剖学的形
態に近づけるという点で意義は大きく，外鼻の土台と なる骨の不均衡を修正したうえで可動性外鼻の修正を 行った方が，長期的に安定し，しかも良好な形態が得 られやすいと考えられる。

近年顎裂への骨移植は咬合形成との関連から犬歯萌 出前, 8〜11 歳程度が最もよいとされている6，7) が, 以上より，すでに咬合形成が終了した成人症例におい ても，口唇外鼻の変形の一因として顎裂の存在がある 限り顎裂部骨移植の積極的な適応があると考えられた。

\section{結語}

顎裂部骨移植，鼻翼部軟骨移植を併用した口唇外鼻 修正術について報告した。この方法は, 軟組織のズレ や痏痕拘縮を修復するのみならず，先天的に欠損また は形成異常をともなっている骨と軟骨を同時に修正す るため，長期的に安定した良好な口唇外鼻形態が得ら れる方法と考えられた，すなわち，成人症例において も，口唇外鼻変形の一因として顎裂という存在がある 限り，顎裂部骨移植術の積極的な適応があると考えら れた。

最後に，口唇外鼻修正に関し数多くのご指導をいただ きました東海大学医学部形成外科学講座教授, 長田光博 先生ならびに提示症例の鼻中隔秋曲修正術を担当してい ただきました積仁会島田総合病院耳鼻咽喉科部長, 矢崎 裕久先生に心より感謝申し上げます

本論文の要旨は第 40 回日本口腔外科学会総会 (平成 7 年 10 月 19 日東京) において発表した。

\section{引用 文 献}

1）高戸 毅, 赤川徹弥, 他：Open method を利 用した唇裂鼻形成術の経験. 日口外誌 40: 2993011994.

2）飯野光喜, 斎藤哲夫, 他：顎裂部骨移植時の下 鼻甲介部分切除. 日口蓋誌 21: 42-48 1996.

3) Jackson, I.T., Vandervord, J.G. et al.: Bone grafting of the secondary cleft lip and palate deformity. Br.J Plastic Surg 35: 345-353 1982.

4）丹下一郎：口唇裂の二次修正. 手術 45: 776-783 1991.

5）三村 保：口唇外鼻の二次修正一特に外鼻に ついて一. 日口外誌 30: 542-551 1984.

6）幸地省子,越後成志，他：顎裂部に対する自家 腸骨海綿骨細片移植. 第 2 報 骨架橋形成につい て. 日口外誌 33: 2152-2158 1987.

7）飯野光喜, 幸地省子, 他：永久歯咬合形成から 見た顎裂に対する骨移植術の手術時期に関する 検討. 日口蓋誌 19: 249-256 1994. 